\title{
Self-Regulation and Peer Influence as Determinants of Senior Secondary School Students' Achievement in Science
}

\author{
Dr Olasehinde, Kayode John \\ Department of Science Education, Federal University, Dutsin-Ma, Katsina State \\ olasehindekayodej@gmail.com \\ Dr Olatoye, Rafiu Ademola \\ Department of Science Education, Federal University, Dutsin-Ma, Katsina State \\ kingdemola@yahoo.com
}

\section{Doi:10.5901/mjss.2014.v5n7p374}

\section{Abstract}

\begin{abstract}
The study investigated self-regulation and peer influence as determinants of senior secondary school students' achievement in science. Descriptive research design was used to carry out the study. Two hundred and four (204) students were randomly selected from the three geopolitical zones of Katsina State. Three (3) instruments were used to collect data for the study viz: (1) Self-Regulation Questionnaire (SRQ); (2) Peer Influence Questionnaire (PIQ); and (3) Science Achievement Test (SAT). Data collected were analysed using Multiple Regression, Linear Regression, Pearson Product- Moment Correlation Coefficient and $T$-test. The findings revealed that self-regulation and peer influence together accounted for $1.2 \%$ of the total variance in science achievement. ( $R 2=0.012, p>0.0$ ); self-regulation alone accounted for $0.8 \%$ of the total variance in science achievement $(R 2=$ $.008, p>0.05)$; peer influence alone accounted $t$ for $0.0 \%$ of the total variance in science achievement ( $R 2=0.000, p>0.05)$. There was a positive significant relationship between self-regulation and peer influence $(r=+0.399, p>0.05)$; there was a positive but not significant relationship between science achievement and self-regulation $(r=+0.090, p>0.05)$. There was no significant difference between male and female students in self-regulation, peer influence and science achievement $(t=-1.777$, 0.218 and $0.678, p>0.05$ respectively). It was recommended among others that teachers should be able to counsel students to manage their time and avoid negative peer influence that might negatively affect their performance.
\end{abstract}

Keywords: Self-regulation, peer influence, secondary school students, achievement in science

\section{Introduction}

Self-regulation is the process of taking control of and evaluating one's own learning and behaviour. Self-regulated learning (SRL) is an integrated learning process consisting of the development of a set of constructive behaviours that affect one's learning. These processes are planned and adapted to support the pursuit of personal goals in changing learning environment. Self-regulation emphasises autonomy and control by the individual who monitors, directs and regulates actions towards goals of information acquisition, expanding expertise and self-improvement ( Paris \& Perru, 2001).

Self-regulated learners are cognisant of their academic strengths and weaknesses and they have the repertoire of strategies to appropriately apply to tackle the day- to-day challenges of academic tasks. The learners hold increment beliefs about intelligence as opposed to entity or fixed views of intelligence and attribute their successes or failure to factors such as efforts expended on a task, effective use of strategies and their controls (Dweck \& Leggett, 1988; Dweck \& Master, 2008). Students who are self-regulated learners believe in opportunity to take on challenging tasks, practice their learning, develop a deep understanding of subject matter and exert efforts that will give rise to academic success (Paris \& Perru, 2001).

Peer is a person who has equal standing with another or others. ( Siegle, 2006). Wikipedia Encyclopaedia (2012) defines peer group as a group of people who, through hormophily, share similarities such as age, background and social status (Siegle, 2006). Influence is the power to affect the way someone or something develops, behaves or thinks without using direct force or orders. Peer influence is used in this research as people of equal standing; age group, classmate or people of the same character on member of the same group. Peers are likely to influence one another's beliefs and behaviour. Vygotsky (2005) in his theory on sociocultural in influence which focuses on the importance of child's culture in 
the society notes that a child is continually acting in accordance with the level of his or her social interaction with others.

Despite this background, researchers still contend the effect of peer influence on academic achievement. Salleh (2011) asserted that students were not negatively influenced by their peers in decision- making but that peer gives positive influence on their achievement in academics and make them differentiate between wrong and right. Adeyemo and Torubelu (2008) said self- efficacy, self-concept and positive peer relations were effective in predicting students' academic performance. In a study on peer influence, pupils' interest in schooling and academic achievement, Adika and Toyobo (2007) reported that both peer influence and pupils' interest correlate significantly with academic achievement.

According to Burke and Sass (2008), peer effect depends on students' ability and on the ability of the peers under consideration. Peer effect tends to have smaller impact when teacher-related factors are included, a result that suggests significant combined influence of peer and teacher quality on students' behaviour. Peer effect tends to be strong at the classroom level than the grade level (Burke \& Sass, 2008). Oloyede and Olatoye (2005) reported that there was no significant relationship between peer influence and study habit; peer influence did not predict study habit; peer influence accounted for $0.0 \%$ of the total variance in adolescents' study habits; there was no significant difference between male and female adolescents both in the levels of peer influence and study habit.

Bolatito, Olugbemiro, and Oyebanji (2011) reported that a comprehensive review of the literature on gender differences reveals that the factors which have been found responsible for the gender imbalance in science could be grouped into six broad categories :individual factors (Baker \& Leary, 1995); cognitive factors (Forrest, 1992); attitudinal factors (Catsambis, 1995); home and family factors (Simpson \& Oliver, 1990); educational factors (Jegede \& Okebukola, 1992). Intervention programme have been mounted in several parts of the world to engage more girls and women in science and science- related careers. According to Kahle and Meece (1994), most intervention programmes were carried out with the objectives of (i) demasculinizing and demystifying science (ii) improving girls' confidence and selfperceptions of their ability to do science; (iii) implementing teaching and learning strategies that actively involved girls in science lessons; and developing girls' skills of doing science.

Two decades of intervention indicates that the gender gap is closing in mathematics achievement. Unfortunately, the reverse is the case with science achievement (Kahle \& Meece, 1994). It has been reported that, in the USA, women constitute only 16 per cent of all employed scientists and engineers while 30 per cent and 21 per cent of the degrees awarded at the bachelors and doctorate degrees in natural science and engineering respectively go to women (Vetter, 1990). In Nigeria, the picture is even more gloomy and abysmal. The Science Teachers' Association of Nigeria (STAN), (1992) reported that less than 10 per cent of the total enrolment in Nigerian universities for science and technology based disciplines are females, only six per cent of those who enrolled in West African and the Senior Secondary School Certificate Examinations are girls, and less than five per cent of the academic staff in Nigerian Universities engaged in science-related disciplines are women. This must also be weighed against the backdrop of the fact that females make up not less than $50 \%$ percent of the country's about 160 million inhabitants in which less than 30 per cent of the girls in secondary schools take science subjects (STAN, 1992). This question certainly needs to be answered by examining ways by which we can considerably reduce, if not eliminate, the gender gulf in science.

Emerging data on differential gender performance in science seem to indicate that elementary students do not exhibit any gender differences in achievement and attitudes toward science (Shaw \& Doan, 1990), that gender differences begin to appear in the middle grades (Catsambis, 1995), and also that gender gap in science achievement increases from age 9 and 13 (Kahle \& Meece,1994). From these reports, it would appear that school-related and other factors take over at a point when the prior (indigenous) knowledge and attitude the students have brought into the classroom begin to wear out.

Therefore, the study examined self-regulation and peer influence as determinants of secondary school students' achievement in science.

\section{Research Questions}

The following research questions are answered in this study:

1. What is the combined influence of self-regulation and peer influence on senior secondary school students' achievement in science?

2. What is the relative contribution of self-regulation to students' achievement in science?

3. What is the relative contribution of peer influence to students' achievement in science?

4. Is there any significant relationship between each of the independent variables (self-regulation and peer influence) and students' achievement in science?

5. Is there any significant difference between male and female students' 
(i) Self-regulation;

(ii) Peer influence and

(iii) Science achievement?

\section{Methodology}

\subsection{Research Design}

The descriptive survey research design was employed to carry out this study. The aim of the researchers was to record, analyze and interpret the existing conditions or variables. The research is non-experimental and therefore variables were not manipulated. This makes descriptive survey research design suitable for this study. This design also accommodates generalization of findings of the study upon the target population from which only a representative or sample was actually studied.

\subsection{Target Population and Sample}

The target population for the study comprised all the students in senior secondary school two in Katsina State, Nigeria. Katsina state is one of the 36 states in Nigeria. It has cultural and educational similarities with the six other states in the North-Western region of Nigeria. Katsina state was divided into 3 zones namely: Daura, Funtua and Katsina senatorial districts. This is the existing political divisions in the state. A random sample of one local Government Area (LGA) was selected from each zone. From each Local Government Area, a random sample of two public and two private schools were selected from each LGA and a total of 12 schools (6 public and 6 private schools) were selected from the entire state. From each school, twenty SS2 Science Students were randomly selected to participate in the study. Therefore a total of 240 students participated in the study. The average age of the students is 15 years.

\subsection{Instrumentation}

Three instruments were used to collect data for this study. They are:

(i) Self-Regulation Questionnaire (SRQ)

(ii) Peer Influence Questionnaire (PIQ)

(iii) Science Achievement Test (SAT)

SRQ and PIQ were designed by the researchers. Each of these questionnaires has 12 items with a four-point Likert-type scale of Strongly Agree, Agree, Disagree and Strongly Disagree. The respondents were asked to indicate their feelings to each statement/item by ticking any of the four possible responses on the scale. The items on the instruments cover different aspects of the variables being considered. Respondents were asked to indicate their gender and type of school on the questionnaire.

SAT is a 30-item achievement test that covers the three core subjects in science namely Biology, chemistry and physics. Ten items were drawn from each of these subject areas.

Examples of items on SRQ:

'I don't need anybody to monitor me before I study very well'.

'I control my time very well'.

'I tried not to be too dependent on others'.

Examples of items on PIQ:

'My friends have much influence on my behaviour'

'I like to be in the midst of my friends always'

'My friends influence the way I talk and view things'

Examples of items on SAT:

1. A group of closely related organisms capable of interbreeding to produce fertile offspring are known as members of (a) kingdom (b) class (c) family (d) species

2. How many orbital is in the d-sub shell? (a) 1 (b) 3 (c) 5 (d) 7.

3. The derived unit of pressure can be expressed as: (a) $\mathrm{Kgms}^{-2}(\mathrm{~b}) \mathrm{Kgm}^{-\mathrm{s}}{ }^{-2}(\mathrm{c}) \mathrm{Kgm}^{-2} \mathrm{~s}^{-2}(\mathrm{~d}) \mathrm{Kgm}^{-1} \mathrm{~s}^{2}$

The content validity of the two questionnaires and the achievement tests was ensured through experts' suggestions and guidance. Experts in questionnaire construction helped in critiquing the items. All the achievement items were selected from already standardised items produced by the West African Examination Council. The items selected 
were only on the topics covered in all the schools selected for the study. The test retest reliability yielded $0.874,0.853$ and 0.826 coefficients for SRQ, PIQ and SAT respectively.

\subsection{Method of Data Analysis}

The data collected were analysed using statistical package for Social Sciences (SPSS) version 17.0. Research question 1 was answered using multiple regression, research questions 2 and 3 were answered using linear regression, research question 4 was answered using Pearson product-moment correlation while research question 5 was answered using ttest.

\section{Results}

4.1 Research Question 1: What is the combined influence of self-regulation and peer influence on senior secondary school students' achievement in science?

Table 1: Peer Influence and Self-Regulation as Predictors of students' Science Achievement

\begin{tabular}{|}
\begin{tabular}{|c|c|c|c|c|c|c|}
\hline $\mathrm{R}=0.109$ & Adjusted $\mathrm{R}$ square $=0.002$ \\
$\mathrm{R}^{2}=0.012$ Standard Error $=3.15129$ & Sum of Square & Df & Mean Square & $\mathrm{F}$ & Sig & Remark \\
\hline & 23.879 & 2 & 11.940 & & & \\
\hline Regression & 1996.057 & 201 & 9.931 & 1.202 & 0.303 & NS \\
Residual & 2019.936 & 203 & & & & \\
Total &
\end{tabular}
\end{tabular}

NS=Not significant $(p>0.05)$

Table 1 reveals that the two independent variables (peer influence and self-regulation) account for $1.2 \%$ of the total variance in students' science achievement $\left(R^{2}=0.012, p>0.05\right)$. The influence of the two variables put together is not significant. This denotes that other factors which account for $98.8 \%$ of the remaining variance were not considered in this study.

\subsection{Research Question 2: What is the relative contribution of self-regulation to student achievement in science?}

Table 2: Self-regulation as a predictor for Science Achievement

\begin{tabular}{|l}
\begin{tabular}{|c|c|c|c|c|c|c|}
\hline $\mathrm{R}=0.090$ Adjusted $\mathrm{R}$ square $=0.003$ \\
$\mathrm{R} 2=0.008$ Standard Error $=3.14931$ \\
\hline & Sum of Square & Df & Mean Square & $\mathrm{F}$ & Sig & Remark \\
\hline Regression & 16.468 & 1 & 16.468 & & & \\
Residual & 2003.468 & 202 & 9.918 & 1.660 & 0.199 & NS \\
Total & 2019.936 & 203 & & & & \\
\hline
\end{tabular}
\end{tabular}

NS=Not significant $(p>0.05)$

Table 2 shows that self-regulation accounts for $0.8 \%$ of the total variance in students' science achievement $\left(R^{2}=0.008\right.$, $p>0,05)$. This implies that self- regulation has low influence on science achievement. Researchers need to look outwards for what variables that could account for the remaining $99.2 \%$ variance on science achievement.

\subsection{Research Question 3: What is the relative contribution of peer influence to students' achievement in science?}

Table 3: Peer Influence as a Predictor for Science Achievement

\begin{tabular}{|c|c|c|c|c|c|c|}
\hline \multicolumn{7}{|c|}{$\begin{array}{l}\mathrm{R}=0.019 \quad \text { Adjusted } \mathrm{R} \text { square }=0.005 \\
\mathrm{R}^{2}=0.000 \quad \text { Standard Error }=3.16163\end{array}$} \\
\hline & Sum of Square & Df & Mean Square & $\mathrm{F}$ & Sig & Remark \\
\hline $\begin{array}{c}\text { Regression } \\
\text { Residual } \\
\text { Total }\end{array}$ & $\begin{array}{c}.765 \\
2019.171 \\
2019.936\end{array}$ & $\begin{array}{c}1 \\
202 \\
203\end{array}$ & $\begin{array}{c}.765 \\
9.996\end{array}$ & .077 & .782 & NS \\
\hline
\end{tabular}

$N S=N o t$ significant $(p>0.05)$ 
Table 3 reveals that peer influence accounts for $0.0 \%$ of total variance in science achievement $\left(R^{2}=.000, p>0.05\right)$. This shows that peer influence do not in any way influence students' science achievement. Thus other factors account for $100 \%$ variance in science achievement.

4.4 Research Question 4:Is there any significant relationship between each of the independent variables (self-regulation and peer influence) and students' achievement in science?

Table 4: Relationship between each of the Independent Variables (Self-regulation, Peer Influence and Science Achievement)

\begin{tabular}{|l|c|c|c|}
\hline \multicolumn{1}{|c|}{ Variables } & Self-regulated learning & Peer Influence & Science Achievement \\
\hline Self-regulated learning Pearson Correlation & 1.00 & $.399^{\star \star}$ & .090 \\
Sig.(2-tailed) & & .000 & .199 \\
N & 204 & 204 & 204 \\
\hline Peer Influence Pearson Correlation & $.399^{\star *}$ & 1.00 & -.019 \\
Sig.(2-tailed) & .000 & & .782 \\
N & .199 & 204 & 204 \\
\hline Science Achievement Pearson Correlation & .090 & -.019 & 1.00 \\
Sig.(2-tailed) & .199 & .782 & \\
N & 204 & 204 & 204 \\
\hline
\end{tabular}

Table 4 shows that there is a significant positive relationship between self-regulation and peer influence $(r=+0.399, p<$ 0.05). This implies that the higher the level self-regulation, the higher the peer influence, the lower the level self-regulation the lower the peer influence. There is also a positive but not significant relationship between science achievement and self-regulation $(r=+0.090, p>0.05)$. The result further shows that there is a negative but not significant relationship between peer influence and science achievement ( $r=-.019, p>0.05)$.

\subsection{Research Question 5: Is there any significant difference between male and female students'}

(i) Self-regulation;

(ii) Peer influence and

(iii) Science achievement?

Table 5: Comparison of Gender in each of the Independent Variables (Self-regulation, Peer Influence) and Science Achievement

\begin{tabular}{|c|c|c|c|c|c|c|c|c|c|}
\hline Variables & Gender & $\mathrm{N}$ & Mean & Std Dev & Std Err Mean & $\mathrm{df}$ & $T$ & p & Remark \\
\hline Self-regulation & $\begin{array}{c}\text { Male } \\
\text { Female }\end{array}$ & $\begin{array}{c}119 \\
85\end{array}$ & $\begin{array}{l}38.2521 \\
395294\end{array}$ & $\begin{array}{l}5.22578 \\
4.82451\end{array}$ & $\begin{array}{l}.47905 \\
52329\end{array}$ & 202 & -1.777 & .077 & NS \\
\hline Peer Influence & $\begin{array}{c}\text { Male } \\
\text { Female }\end{array}$ & $\begin{array}{c}119 \\
85\end{array}$ & $\begin{array}{l}34.4034 \\
34.2118\end{array}$ & $\begin{array}{l}6.35039 \\
5.94838\end{array}$ & $\begin{array}{l}.58214 \\
.64519\end{array}$ & 202 & .218 & .828 & NS \\
\hline Science Achievement & $\begin{array}{c}\text { Male } \\
\text { Female }\end{array}$ & $\begin{array}{c}119 \\
85\end{array}$ & $\begin{array}{l}7.0840 \\
7.3882 \\
\end{array}$ & $\begin{array}{l}3.05203 \\
3.30258\end{array}$ & $\begin{array}{l}.27978 \\
.35821\end{array}$ & 202 & .678 & .498 & NS \\
\hline
\end{tabular}

NS= Not significant $(p>0.05)$

Table 5 shows no significant difference between male and female students in self-regulation, peer influence and science achievement $(t=-1.777,0.218$ and .678 respectively, $p>0,05)$. With the mean score of 39.53 , female students are more self-regulated than their male counterparts with 38.25 mean score. The male students have the mean score of 34.40 which shows that they are more influence by their peers than their female counterparts with the mean score of 34.21 . Female students have higher science achievement mean score of 7.38 whereas male students mean score is 7.08 . This shows that the female performed better in science achievement than the male. Generally, the performance of students in science is below average. The maximum obtainable score is 30 . The mean scores for both male and female students are very poor. However, it is most important to note that there is no significant difference between male and female students in each of these three variables namely self-regulation, peer influence and science achievement. 


\section{Discussion}

The result of the research among other shows that self-regulation and peer influence taken together account for $1.2 \%$ of the total variable in science achievement. These two independent variables are not the real determinants of science achievement in this study.

Self-regulation predicted science achievement at $0.8 \%$. This is very negligible and it is also contrary to the submission of Paris and Perru (2001) who asserted that students who are self-regulated learners believe in opportunity to take on challenging tasks, practice through learning, develop a deep understanding of subject matter and exert efforts which will give rise to academic success. The position of Paris and Perru (2001) was negated by the result of the research. The reason for the low variance may not be unconnented with the fact that students direct most of their time to other activities such as facebook, telephone and to go etc.

The findings also corroborated Oloyede and Olatoye (2005) who reported that peer influence accounted for $0.0 \%$ of the total variance of adolescents' study habit. The results of this research do not support the report of Salleh (2011) and Adeyemo and Torubelu (2008) which asserted that peer influence has positive impact on students' academic achievement. Through there no is influence of peer on students' achievement in science, however, it may be that the influence of peers on students is directed towards other things outside achievement in science.

The results show that there is a significant positive relationship between self-regulation and peer influence. Also, there is a positive but not significant relationship between self-regulation and science achievement. Peer influence has negative but no significant relationship with science achievement. The significant and positive relationship between selfregulation and peer influence could be used by teachers to make positive change in the students' science achievement. The potential of teachers' effect in this area cannot be ignored. Ample opportunity is created for the teachers to work and drive the students' science achievement higher.

Reports show that there is no significant difference between male and female students' in self-regulation, peer influence and science achievement. Also, Oloyede and Olatoye (2005) reported that there is no significant difference between male and female adolescent students, in study habit and peer influence which attests to the fact that both gender could regulate their learning and thereis no reason to expected significant difference between them which is the findings of this research. No significant gender difference in science achievement which is a finding of this research supports Olagunju's (1998) reported. The poor science achievement may also be traced to poor students' background and their poor preparation for senior secondary school level.

Olatoye (2002) opined that science education lays foundation for work in science-related fields by acquainting learners with certain knowledge and skills. With the very low achievement of students in science reported in this study, there is need to look outside the factors considered in this study. According to Olatoye ((2009a, 2009b), factors such as test anxiety, motivation for examinations, study habit self-concept have significant influence on students' achievement in science.

\section{Conclusion}

This study obviously provides an empirical evidence that self-regulation and peer influence are not the main factors affecting students' achievement in science especially secondary schools in Katsina State, Nigeria which is the target population. Researchers should there fore try to conduct more researches to really unravel those factors or variables that account for significant variance in students' science achievement. Such variables could be level of parents' education, knowledge of English Language, availability of instructional materials and teacher qualification, among others.

However, this study does not disprove the findings of other researchers who reported that the independent variables considered in this study ( self-regulation and peer influence) are important in raising science achievement.

\section{Recommendations}

A major finding in this study is the significant positive relationship that exist between peer influence and self-regulation. Teachers should be able to counsel students to manage their time very well and avoid negative peer influence that might negatively affect their self-regulation which might in turn affect their achievement in science. The performance of students in science is below average in this study. This implies that all the stakeholders in education should ensure conducive environment and support are give to the study of science. 


\section{References}

Adeyemo, D.A. and Torubelu (2008). Self-Efficacy, Self- Concept and Peer Influence as Correlates of Academic Achievement Among Secondary School Students in Transcution, Pakistan. Journal of Social Sciences 5(1), 10 - 16 http://medicinel/journals.com

Adika L.O. \& Toyobo, O.M. (2007). Relationship between Peer Influence, Pupils Interest in Schooling and Academic Achievement. The Social Sciences; 2, 436 - 441 http://medwelljournals.com

Baker, D, \& Leary , R (1995). Letting Girls Speak Out about Science. Journal of Research in Science Teaching,3( 1), 3-27.

Bolatito, A. L. Olugbemiro, J J. \& Oyebanji, P. K.(2011) Towards Eliminating the Gender Gulf in Science Concept Attainment Through the Use of Environment Analogs

Burke, M. A. \& Sass, T. (2008). Classroom Peer Efforts and Students Achievement. Urban Institute. Publicaffars@urban.org

Catsambis, S. (1995). Gender, Race, Ethnicity, and Science Education in the Middle Grades. Journal of Research in Science Teaching, 32(3), 243-257.

Dweck C.S. \& Master, A. (2008). Self Theories .Motivate Self-Regulated Learning. In: Schunk D.H. and Zimerman (Eds). Theory, Research and Applications. . 31 - 51 New York. Lawrence Eriba Associations.

Dweck, C.S. \& Legget, E. (1988). Social Cognitive Approach to Motivate and Personality. Psychological Review 95:256 - 273.

Forrest, G.M.(1992). Gender Differences in School Science Examination .Studies in Science Education, 20:87-121.

Jegede, O.J., \& Okebukola, P.A.O.(1992). Differences in Sociocultural Environment Perceptions Associated with Gender in Science Classrooms. Journal of Research in Science Teaching, 29 (7), 637-647.

Kahle, J.B., \& Meece, J (1994). Research on Gender Issues in the Classroom. In: D. Gable (Ed.). Handbook of research on science teaching, .New York: MacMillan Publishing Company, 542-557.

Longman Dictionary ( ). Peer and Group http://dictionary.reference.com

Olagunju, A.M. (1998) The Impact of Two Curriculum Packages in Environmental Education in Biology on Learners Performance, Problem Solving Ability and Environmental Attitude. Unpublished Ph.D. Thesis, Teacher Education Department, University of Ibadan

Olagunju, A.M. \& Olasehinde, K.J. (2011). The impact of Gender and two Scheme Based Instructional Strategies on Students' Cognitive Achievement in Population Education Concept in Biology. East African Journal of Educational Research and Policy (EAJERP) 6 , 53-163.

Olasehinde, K.J. (2008) . Impact of Two Scheme-Based instructional Strategies on Students' Learning Outcomes in Population Education Concepts in Biology. Unpublished Ph.D. Thesis , Teacher Education Department, University of Ibadan.

Olatoye, R.A, (2002). A Causal Model of School Factors as Determinants of Science Achievement in Lagos State Secondary Schools. An Unpublished PhD Thesis, University of Ibadan, Nigeria.

Olatoye, R A. (2009a). Study Habit, Self-concept and Science Achievement of Public and Private Junior Secondary School Students in Ogun State, Nigeria. African Research Review, 13 (4),

Olatoye, R. A. (2009b) Students' Test Anxiety. Motivation for examinations and science achievement in junior secondary schools in ogun state, Nigeria. International Journal of Psychology and Counselling,1 (10), 194-198.

Oloyede, D.O. \& Olatoye, R.A. (2005). Peer Influence on the Study Habit of Secondary School Adolescents in Ogun State, Nigeria. African Journals Online (AJOL) http://www.apl.info/index.php/ifep/artilce/view23678 Retrived10th April,2013.

Oyedeji, A.O. (1996) Assessing Gender Factors in Some Science and Mathematics Test in Nigeria. Journal of Education Research 8 (1), $45-53$.

Paris, S.G. \& Perru, A.H. (2001). Classroom Application of Research on Self-Regulated Learning. Educational Psychologist, 36:2; 89 101. Retrieved 10/4/2013 from the Education Complete Research Data Base.

Printrich, P.R. (2002). The Role of Goal Orientation in Self-Regulation Learning. In: M. Boekaety, P.R. Pintrich and Zeinder( Eds.) Hand Book of Regulation. Diego academic press. $451-501$.

Salleh, M.J. (2011). Peer Influence in Academic Achievement and Behaviour Among Students of Mara Science College, Malaysia. National Seminar on Counselling Across Culture. Pekema. http://rop.iicim.edu

Shaw, E.L.,\& Doan, R.L. (1990). An Investigation of the Differences in Attitude and Achievement Between Male and Female Second and Fifth Grade Science Students. Paper Presented at the Annual Meeting of the National Association for Research in Science Teaching, Atlanta, GA.

Siegler, R. (2006). How Children Develop, Exploring Child Development. Student Media Tool Kit and Scientific American Reader, New York: Worth Publisher

Simpson, R.D \& Oliver, J.S. (1990). Attitude toward Science Achievement Motivation Profiles of Male and Female Students in Grades 6 through 10. Science Education, 69 (4), 511-526.

Vetter, B.M. (1990). Women in Science and Engineering: An illustrated Report. Commission on Professionals Science and Technology. Washington, DC:

Vygotsky, S. L.(2005). An Introduction to Social Content Theory $2^{\text {nd }}$ Edition. New York. Http://www/lib-uwocaproxy2.lib.uwo.ca/cgibin/ezpartlinci/docview/620967172?

Wikipedia Encyclopaedia (2012). Peer Group. http://en.wikipedia.org/wiki/peer_groupmw-navigation Retrieved May $23^{\text {rd }}, 2013$.

Zimmerman, B.J. (1990). Self Regulated Learning and Academic Achievement: An Overview Educational Psychologist. 25 (1) 